BMC JOURNAL OF SCIENTIFIC RESEARCH

A Multidisciplinary Research Journal

ISSN: 2594-3421

\title{
Speculative Creation of Vedic Hymns: Hermeneutic Approach to the Selected Verse
}

\section{Surendra Ghimire*}

\begin{abstract}
The article, specifically, aims to make a knowledge contribution in epistemology, especially intuition and speculation two approaches of knowledge making. At the same time, it engages into Vedic study by revealing the process of creating the hymns and verses that are compiled in the texts. Some selected verses from the Rigveda translated by Ralph Thomas Hotchkin Griffith (1896) were taken as a source of information. Conceptual analysis of these verses and hymns suggests a pattern which indicates that these were created skeptically rather than authoritatively, and synthesized with microcosm-macrocosm analogy. On the other hand, there is no evidence of intuitive approach of creating the verses. Since an argument- 'the knowledge was created speculatively by the then scholars not intuitively by the seers' is put forward. Hence, the paper demystifies the mystified knowledge surpassing the blasphemy of Veda, against the faith of uncreated religio-philosophical text the hermeneutic interpretation presents, as a reflective and scholarly act, an opposite epistemological perspective.
\end{abstract}

Keywords: Intuition, Micro-macro analogy, Skepticism, Speculation, Vedic hymns

\section{Introduction}

Etymologically the Sanskrit word Veda refers to knowledge. Aurobindo (1998, p. 5) adds for this knowledge as- the highest spiritual truth of which the human mind is capable.

Veda which is recognized as a holy religious text is not only a collection of knowledge but hallmark of the real beginning of philosophy that is observed in its systematic and logical organization. Among the four Vedas, the Rig carries a paramount importance for its philosophy and the unique anthropomorphosis (Bloomfield, p. 29). Veda contains the qualities of the best and oldest written text (Bloomfield, p. 33), integrated and coherent structure (Pfleiderer, 1893, p. 1), and the most perfect meter and polished language (Muller, 1901, p. 231; Bloomfield, p. 30). Two curiosities sprang out as protuberance from this apex and worthy features - how the oldest knowledge of the world that is accumulated in the Veda was acquired; what methods or approaches or paradigms were used to acquire this worthiest knowledge?

These debating questions divided scholars into two camps of epistemological (Kirschner, 2009, p. 144) realms: intuition versus speculation to answer these questions. The folk knowledge claims that the Veda is hearing (Sruti) and non-created by human being (Apaurusheya), that is the revealed knowledge or intuition through god's intoxication (Ranade, 1926, pp. 9 \&10). Explanation the hypothesis of "hymns were created without human endeavor" is similar to the

\footnotetext{
* Mr. Ghimire is Lecturer in Education at Birendra Multiple Campus (Tribhuvan University)
} 
principle of radio transmission- certain radio station transmits information in certain frequency and it is made audible by radio set. Generally a set catches the wave of only one station (frequency) at certain instant of time. Cosmic knowledge from beginningless time has been vibrating in different radio frequencies. The ancient seers through meditation developed their power to catch these one or more frequencies and transferred into audible hymns. These hymns by different seers, Sanskrit drasta (Aurobindo, 1998, p.10) were later compiled. Acceptance of the hypothesis of Apurusheya compels us to inferring- "Vedic hymns in the form of cosmic waves or sounds are still available, we can perceive it if we develop our mind accordingly". However, till now, there is not enough evidence of such advancing of mind in scientific approach.

Prominent Indian Vedic scholars opine that Vedic knowledge was acquired via this Apurusheya approach of knowing. This is defined as mysticism in philosophy (Radhakrishnan, 1989, p. 265; Ranade, 1926, p. 2), revelation in religion (Burch, 1962, pp. 297\& 298), and intuition in psychology (Sherin, 2006, p. 536), nevertheless, this is a method of direct perception. Ranade (1926, pp. 5 \& 17) and Radhakrishnan (1989, p. 179) endeavored to prove intuition is complementary to reason and understanding. The intuitional method, for Ranade, subsumptive of reason and not contradictory of the logical and for Radhakrishnan, can throw light on the dark places which intellect is not able to penetrate. Hence, these two renowned Vedic scholars claimed that the Vedic hymns were created by seers intuitively.

On the other hand, western Indologists such as Ganeri (1996, p.10), Hayes and Gillon (1991, p.1) claim that the ancient human used speculation as a method for advancing knowledge. Cowell and Gough $(1882$, p.43) suggest that in the process of speculating individual cosmic forces, they arrived to develop a comprehensive structural functionalism that is principle of Rita. Elenjikal $(1949$, p.2) opines that the Veda is the window through which the ancient Aryans first looked into infinitude. The initial philosophical mind of early Indo-Aryans saw something behind the sensible manifestations. Deifying the powers of natural functioning was the result of their immature philosophical speculation due to its Vedic sages asserted that every impressive phenomenon of nature, every group of physical forces of nature corresponded to an insensible power, for example they named Indra as the rain (indu) god- "The chanters hymns... the word of praise magnify thee ... Indra observes this wish of his, and the rain hastens with his troop" (RV I. 10).

This knowledge on the one hand, casts light on ancient text which is regarded as a pride of human civilization, on the other, further clarifies intuition and speculation as methods of epistemology. Paper at surface seems as knowledge for the sake of knowledge; however, in depth it has educational implication. This paper, at first, makes a brief discussion on speculation and intuition, and then presents the selective hymns from Rig Veda translated by Ralph Thomas Hotchkin Griffith as information of this study, and finally, analyses these hymns with the perspectives of epistemology and concludes that Vedic hymns were created with speculative approach rather than intuitive.

\section{Two Approaches of Philosophizing: Intuition and Speculation}

There are two approaches which represent distinctly different camps of philosophizing. As 
Bertrand Russell opines (1945, p.12), philosophy oscillates between the faith approach of religion and experiment approach of science. Since, philosophy deals all the approaches and contents of this middle zone between the realms of theology and science. Inside this premise intuition stands in one end with its judgmental truth without being its justificatory source and fact. Speculation, in another end, stands with reflective and analogical methods by magnifying little sources and facts to the broad statement.

\section{Intuition}

Intuition is believed to emerge when mind reaches to certain level of development by training. For intuition, the mind should be shifted to 'altered state of consciousness 'ASC' (Winkelman, 2002, p. 1878). During ASC certain chemicals are produced in brain and in this process the external circuit is blocked, and the inner world dominates (Olliges, 2010, p. 8), thus, one feels transcendental consciousness and feelings of ecstasy. Feeling of knowing something in such state of consciousness is often referred to as a "mystical experience" (Miller, 2007, p. 1). Intuition in normal state of consciousness is impossible, since this approach of knowledge making is considered unscientific. It is a kind of power of obtaining knowledge that cannot be acquired either by inference or observation, by reason or experience (Encyclopedia Britannica 15th Edition, 1989). Intuition seems to lack the logical structure of information processing, but it is subjective experience associated with the use of knowledge gained through implicit learning (Lieberman, 2000, p. 109).

Intuition resembles somehow to mystic or supernatural power because it cannot answer to 'if such a power really existed independent from experience and reason, where would it originate'. Intuition is, psychologically, categorized into subconscious mode of thinking largely unconscious, biased, automatic and effortless cognitive process difference to conscious mode of thinking that follows a process of operating as rational, deliberate, analytic, inferential, or reflective and analytical cognition whereas philosophers conceive intuition as rational and superior to analytical thinking (Betsch, 2008, pp. 3-5).

\section{Speculation}

Speculation is considered as scientific method of knowledge that attempts to explain sense data, which is limited by factors of time, space, the defects of human sense organs and the distortion and unclarity inherent in mundane vocabulary and grammar. Speculation meets the criterion of 'to be knowledge, it must pass through either the gate of the senses, or of reason' (Muller, 1901, p. 227). Vedic seers were concentrated in developing knowledge of first principle and their approach was speculation. It demonstrates dual properties: in scientific contexts, it is often close to experience to be refuted or accepted as a testable theory and in more distant metaphysical contexts, theories such as those concerning universals and possible worlds are intended to be consistent with the world of our experience, they do not offer predictions to be tested, per se (Chakravartty, 2007, p. 15). Though, philosophical speculation takes place 'at a distance' from empirical inquiry, it starts from daily experience to move beyond it. Since, it is an endeavor to frame a coherent, logical and necessary system of general ideas in terms of general fact of our 
life in the form of the expression of an adventure and creating novel ideas speculation can be metaphorised as a flight of airplane that starts from the ground of observation makes a flight of thin air of imaginative generalization and it again lands for renewed observation rendered acute by rational interpretation (Siebers, 2002, p. 56). A philosopher, using speculation as a method, tries to abstract and generalize this feature into a flexible principle, capable of manifesting itself in very dissimilar ways in different regions of fact, and such that the differences in its manifestations are connected in an intelligible way with differences in the circumstances (Broad, 1947). In another word- getting reflective knowledge as how it works in this micro level that will work in the same way in macro level which is said macrocosm-microcosm analogy by Morris and Pai (1976, p. 124) is one method of speculation. In the process of philosophizing, speculative knowledge is found expressing truth in skeptical form; the same matter is presented in different ways at different places. On the other hand, intuition presents the directly perceived knowledge with confidence at all. The presenter is so confident that any truth presented anywhere else in the same way intact. This paper presents that the Vedic hymns approach to skepticism and microcosm-macrocosm analogy.

\section{Research Methodology}

The main content of this study is Vedic hymns. They were originally scripted in Sanskrit language. However, I have taken up The Hymns of the Rigveda translated in English by Ralph Thomas Hotchkin Griffith and Published in 1896 by E.J. Lazarus and Co., Benares. Form the text only certain hymns were purposefully selected as Creswell (2012, p. 206) suggests the sampling method. In the most places, verses are quoted as evidence for my statements and in some places of the verses have been interpreted to extract contextual meaning as the hermeneutics (Henriksson \& Friesen, 2012) as method does with the spirit of Wilthem Dilthey (Rickman, 1976) who characterizes modern hermeneutics as liberation of interpretation from dogma (p. 235). Parenthetical citations are modeled like 'RV.X.24.4' that stands for 'Rigveda. 10 th mandala/part $24^{\text {th }}$ hymns/Shukta and 4 th verse/shloka'.

\section{Speculative Pattern in Vedic Hymns}

Analyzing the content of some selected philosophical verses and hymns suggests that the Vedic hymns were created speculatively by the then scholars not intuitively by the seers. The bases to make this argument have been presented below.

\section{Skepticism in Vedic hymns}

There are diverse views on what is skepticism, but, here it refers to a situation of doubting to any truth- as final or absolute but accepting the possibility of another more plausible truth. Skepticism assumes doubt as a tool of enquiry. Greek philosopher Sextus Empiricus was the first man to identify the category of skeptic philosopher (Gupta, 1981 p. 30; Kuzminski, 2008, p. ix). Scholars in ancient India too were skeptic and we have no plausible evidence to argue skeptic approach was transported to Greece. This independent parallelism for what Ranade (1926, p. 101) has explained suggests that philosophers are itself a skeptic in nature.

Rig Vedic hymns are found skeptic in many ideas, among them one which is related to prime 
origin is portrays here. It is mentioned that "...All was indiscriminated chaos. All that existed then was void and formless: by the great power of Warmth was born that Unit. Thereafter rose Desire in the beginning, Desire, the primal seed and germ of Spirit" (RV.X.129). In another place- "From fervor kindled to its height Eternal Law and Truth were born" (ibid, 190): Thence was the Night produced, and thence the billowy flood of sea arose. From that same billowy flood of sea the Year was afterwards produced, Ordainer of the days nights, Lord over all who close the eye. Dhatar, the great Creator, then formed in due order Sun and Moon. He formed in order Heaven and Earth, the regions of the air, and light (RV.X.190. 1-3). In another place"These Brahmanaspati produced with blast and smelting, Existence, in an earlier age of Gods, from Non-existence sprang. Thereafter were the regions born. This sprang from the Productive Power. Earth sprang from the Productive Power the regions from the earth were born. Daksa was born of Aditi (infinite) and Aditi was Daksa's Child. Daksa's daughter Aditi brought forth the Gods with immortal life" (RV.X.72. 2). In another place- "On every side pervading earth he fills a space ten fingers wide. From him Viraj was born; again Purusa from Viraj was born. The Brahman was his mouth, of both his arms was the Rajanya made. His thighs became the Vaisya, from his feet the Sudra was produced. The Moon was gendered from his mind, and from his eye the Sun had birth; Indra and Agni from his mouth were born, and Vayu from his breath. Forth from his navel came mid-air the sky was fashioned from his head Earth from his feet, and from his car the regions. Thus they formed the worlds (RV.X. 90. 12. 1,5,13\&14).

In another place, hymns themselves express the skepticism- "Most excellent are waters, thus said one of you; most excellent is Agni, thus another said. Another praised to many a one the lightning cloud. Then did ye shape the cups, speaking the words of truth" (RV I. 161-9). The Vedic scholars or bard were skeptic whether the prime cause of origin is- water, night, Rita, truth, non-existent, desire, heat etc.

\section{Micro-macro analogy in Vedic Hymns}

Vedic hymns also indicate that they were synthesized with the approach of micro-macro analogy. Such hymns are based on the creators' diverse contexts, among them geographical, psychological, sociological and astronomical are discussed below.

\section{(a) Astronomical base}

For the Vedic seers sky was resourceful to observe, reflect and synthesize metaphysical ideas. Both visible and invisible forces of sky have been addressed in Rigvedic hymns. Vedic gods are divided into three main groups of realms: The celestial or sky (Dyu Loka), the atmospheric (Antariksha Loka) and the terrestrial (Bhu Loka). Aditi the mother of gods denote infinite expansion or dimensions of the horizon and Uttanapada (or uncertain) sprang from Aditi, and from the same horizon, Sun was born (RV.I. 89. 10). Aditi is the prime matter which is physically non-existent in the world of experience-"Aditi all that hath been born and shall be born." Vedic bards observed that space is permanent and changeless, immortal pure and free, from there they drew the concept of immortality otherwise primitives had seen the sun as mortal due to its daily birth and death. The space symbolized as immortal and dwelling place 
of all gods including Indra and Marut etc. (RV I. 40.5). His concerned is into ground than figure because of his marking for space and he supposed to air as ruling force of universe, air is a vital spirit (prana) of gods, which is invisible but hearable to thunder- The singers' for their aid, invoke Indra and Vayu, swift as mind, The thousand-eyed, the Lords of thought (RV. I. 23.3) Planets and sub-planets of the solar system which are visible too were accepted as gods. They knew sun as life-giver- "May Surya guard us out of heaven, and Vata from the firmament, And Agni from terrestrial spots... Thou Savitar whose flame deserves a hundred libations, be thou pleased: From failing lightning keep us safe ... give us sight; May the Creator give us sight" (RV. X. 158.1-3) and presents sun as Viśvedevas, where two brothers are lightening and fire (RV I.164). Sun was praised as immortal and that which hath breath and speed and life and motion lie firmly established in the midst of houses, whereas moon as mortal (RV I.164.30). Angirases, in hymns, has been presented as Asura's Heroes- Bounteous are these, Angirases, Virupas: the Asura's Heroes and the Sons of Heaven (RV III.53.7). Curious observation to the sky fostered the Vedic scholars to categorized planets into gods- the smaller, brighter and downing is master of the Asura (dark) and the bigger, red, and non-downer is master of deva (light). Their opposite direction of revolution was symbolized with rivalry families of Angirases (Jupiter) and the Bhrigus (Venus) in later days. The distance planet Pluto has been recognized as king of death (RV, X.135), the Vedic hymns (gods) Agni, Vayu and Aditya born from the earth, the atmosphere and the sky respectively is very common speculation. Since the knowledge of Veda was synthesized from two eternal: eternal space was the source for eternal nature of human beings to get a reflection.

\section{(b) Psychological base}

Vedic hymns allied to offering, applauds and submission indicate that creating the hymns was inspired with fear psychology of Vedic bards. Their consciousness was up to the level of animistic psychology; they named to the natural forces with human names such as Indra and Varuna. They imposed the cosmic order, Rita through the process of cognitive psychology: a law of completion and integration (Luccio, 2011, p. 3). They speculatively defined natural forces as a powerful human (name and nature), and inferred gods also become happy with a material offering and praise like a human being (RV. IV. 1. 2). The Indra symbol of light is well equipped with Mitra (storm), Pawan (hurricane), Varuna (god to save in dark ), Mitra is colleague who is together as lightning and thunder becomes, since Indra is named, though Mitra is also name but adjective of companion of Indra (RV, III.4.7). The acceptance of subduing is reflected on Veda where the unknown force (cause) has been defined as mighty Indra and prayed as 'Thou borest him as a father bears his son in his lap (RV. X, 69.10, RV. III, 53. 2).

The positive psychology of Vedic sages is reflected on prolonging war between Indra and Vritra"Deep darkness fell upon the slain, and Indra won by victory the right of being first invoked" (RVX.113.7). creation of such hymns may be inspired by two ways: either they were suffered with prolong night and day, since, they created Indra leader of deva (Gods) or light and Vritra leader of asura (demon) or dark, Deva from word div to shine or illuminate and Vritrasura is to represent darkness, or the mind of primitive sages, just sprang from fighting among tribes 
and hunting animals, since they characterized light and dark animation and warfare. However, the context of other hymns favours for symbolic war rather than terrestrial. They applied the psychology of Apollonian and Dionysian (Culp, 2005): they presented Indra, king of the davea (light) always victor against Vritra king of Asura (dark) (RV III. 31. 18-22). In hymns Indra, Agni, and Soma destroyed together with their 'defense' the pur of the asura (Tilak, 1903, p. 116). The inner conflict between the forces of light (knowledge and piety) and those of darkness (ignorance and arrogance) has been symbolized by the supernatural battles between gods and demons. Such a transformation might be done intentionally for pedagogical purpose because learning through concrete things like visible war is easier than through abstract things like invisible human construct. Similarly, Vedic people found Agni a deity of visible, tangible, immediate and of no doubt, since they accepted him as god and a mediator of all other invisible, intangible and distance gods- "we choose Agni the messenger, the herald, master of all wealth, Well skilled in this our sacrifice (RV.I. 12.1)."

Psychology of utility is found ahead than the psychology of skeptic power of other gods (cosmological forces) in later days. Hymns of Agni and Indra were created around 10,000 by food gatherers and occasionally hunters, but Soma around 4000BC (Mahdihassan, 1991, p. 11; William, 2009), which is farthest back of scientific method by depending on Tilak (1903), and date of last ice age (Hermanussen, 2003, p. 175). The anti-fatigue energizer tonic Soma made Vedic seers applaud as a 'god' rather than as a 'plant' since in the IX Mandala of RV and in almost places soma has been given the highest position. Rita is an attempt to theorize the natural forces, because they understood from a theory they can be benefitted by understanding, controlling and predicting and ultimately making safe one's fate. Since, they tried to understand (the Rita or a cosmic law to govern) the different forms, movement, and function of heavenly bodies. They proceeded from the visible to the invisible, from the finite to the infinite. It is the right way of making speculative or metaphysical philosophy. Vedic seers developed the concept of eternal because they found, Vayu, Marut, Pusan, Rudra and all heavenly bodies etc. changeable appear and disappear, but found clear blue sky the boundless firmament of heaven, which is never changed, always the same. They heard the noise of thunder, but could not see the thunder, nor feel, smell, or taste, and conceived as somebody (Indra) is the howler in the sky just as they experienced such howling noise.

\section{(c) Sociological base}

The hymns mentioned here are possibly synthesized in the river bank of Sindhu, Ganga, and Yamuna so that they could applause as- "The Rivers have come forward triply, seven and seven. Sindhu in might surpasses all the streams that flow. O Ganga, Yamuna, O Sutudri, Parusni, and Sarasvati: With Asikni, Vitasta, O Marudvrdha, O Arjikiya with Susoma hear my call. Rich in good steeds is Sindhu, rich in cars and robes, rich in gold, nobly-fashioned, rich in ample wealth" (RV.X. 75.1\&5\&8). The Purusa Shukta tells- "the Brahman was his mouth, of both his arms was the Rajanya made. His thighs became the Vaisya, from his feet the Sudra was produced (RVX 90.12) "indicates that there was Chaturvarna or four-class system. As the scholars observe hierarchy in earthy society they supposed the same in the heaven too. Indra 
was put in a place of king, devoted with the most 250 hymns as lord of war and applauded as- "I am prepared to laud with song or worship the Noble Ones who are in earth and heaven, Or Courses who have triumphed in, the contest, or those who famed, have won the prize with glory" (RV.X.74.1). Along with king of heaven, he has been supposed as 'Guardians of men' (RV.X. 17. 2). Along with the king his priest Brahmanaspati too has been praised as- "Indra's lovely friend who gives wisdom, famed as messenger to god from us taking our voice of praise to the Gods (RV. I.18. 6\&9) " and appealed for saving- "Do, thou, O Brahmanaspati, and Indra, Soma, Daksina, Preserve that mortal from distress" (RV.X.18.12).

Vedic bards hope and appeal as - "Drive all our enemies away, O Indra ... So bring the food for men, bring grass,... as parents aid a son, both Asvins, Indra, aided thee with their wondrous Powers and wisdom" (RV.X.131.1\& 5). Another example of micro-macro analogy is Nasadiya Sukta. As they used to have a desire, kinship and have copulation and found a baby formed with relatively nothing. That idea was shifted to the birth of the universe as- "Thereafter rose Desire at the beginning, Desire, the primal seed and germ of Spirit. Sages who searched with their heart's thought discovered the existent's kinship in the non-existent. Transversely was their severing line extended: what was above it then, and what below it? (RV.X.129.4\& 5). "

Purusha Sukta was created to justify the usability of social hierarchy. The cosmic Purusha is supposed as 'the unborn' or eternal' and it was described as an extreme (Thousand head has Purusha, Thousands of eyes has he, Thousands of legs has He, He is manifested in the earth and all through the universe, He stands beyond the count of ten fingers), so that people could easily accept its power and eternity. From different hierarchical parts of the body of such Purusha, the four castes were born. The Purusa Shukta is the symbol of cosmogonic elements too (RV X.90. 11-14), three elements of the human Body are compared to the three elements of cosmos: head to heaven, naval to atmosphere and feet to earth.

The king and priest had the highest socioeconomic status in this society since they developed the concept of governing king. The very political system is found reflected on the Rita making process, with the psychology of following and follower. Thus Varuna was conceived as a holder of the sky the seat of Rita. Later on, Rita, like Satya (the true), was conceived as the eternal foundation of all that exists. In sociological form, Rita, became the path King Varuna, when the concept of a king was there in ruling the society (RV I, 24.8). Varuna, the god of the allembracing sky, could sometimes be supposed to have settled and determined what in other places is called the Rita, as an independent power - "O thou Leader wide-ruling Varuna, Lord of many heroes. O sons of Aditi" (RV.II. 28.7).Cosmic Rita was the ideal to develop social Rita, where everybody works without desire of fruit: having as its reward the attainment of the bliss of the Supreme Spirit through his propitiation. To justify the worldly pristine they created heavenly priests Brihaspati and Sukra (RV. I. 190. 2).

The term dharma, originated in later Mandala of the Veda (RV.X: 21.3), has been presented as a masculine being who manipulates law and order to support and sustain the whole system, the Dharma raj is sometimes called Yama a 'god of death' which resembles to the function of 'time'. Time as an animistic form is regarded as the most dutiful and punctual entity which appears 
in little earlier Manadalas of Rigveda (RV. I. 22.18, RV.V, 26.16; RV.VIII. 43.24; RV.IX. 64.1) which is now defined as a beginningless or Sanatana or dharma. Developing cosmic structure or Rita making was mere speculation as well as a cunning strategy of imposing the then social practice of masculine superiority.

The enormous power and use of Sun have been appreciated by Vedic philosophers, the radiant sun has been interpreted as- "All-lighting, radiant, mighty as the Sun to see, he spreadeth wide unfailing victory and strength. Beaming forth splendor with thy light, thou hast attained heaven's lustrous realm. By thee were brought together all existing things, possessor of all Godhead, Alleffecting God" (RV. X. 170.3\&4). They symbolized Surya as traveling in a horse with seven reins source of life in the basis of divisions of time into seven units- year, solstice, season, month, fortnight, day, night and hour. Another source of their speculated knowledge according to Tilak (1903) is that the bards used to live in seven- months year of the arctic region. Their pristine practice motivated them to speculate: the Brihaspati or Brahmanaspati 'lord-of-prayer' (I, 190, 2), the divine priest, has been closely linked (I, 33, 13: etc) to Agni purohita 'domestic priest' (I, 1.1), but also allied to Indra in destroying demons and goblins with fire (RV.II, 23, 14; RV.X, 68, 4-8) or with his roar (RV.IV, 50, 5: RV.X, 68, 8-11).

\section{(d) Geographical base}

Certain hymns of Veda reflect that the creators were living in the somewhere northern part. The climate, environment etc. may influence to create such hymns. Vedic hymns present deva or god as superior to asura or demon whereas Zend Avesta presents opposite. Similarly, in hymns (RV.X. 10) Yama repulses his sister Yami's sexual approaches whereas in Iranian culture twins Yima and Yimeh who do unite and produce offspring (Macdonell, 2012, p. 119). Comparing these two concepts gives two ideas; a) common ancestor; Avestan-Irano people and VedicIndo people both were Aryan and had common hymns when both used to live somewhere common land in the Northern part, later they separated and their hymns orally transferred from generation to generation, and over the time their hymns carried opposite meanings, and remain accordingly in their compiled book, both books accept deva/ god and asura/demon as two rivalry forces, b) socio-cultural impact on hymn: time of compilation or creation of the tenth book of RV (or the hymn RV.X. 10) was nearly time of formation of ethical and moral philosophy about sex and reproduction of Indo-Aryan society.

Accepting Tilak's (1903, p. vi) suggestion of the primitive Aryan home was both Arctic and interGlacial gives meaning to certain hymns of Veda, moreover, certain hymns can be interpreted only with the reference of this geographical milieu. Vedic Aryans were migrated southward and they composed new hymns by reflection of new environments. Famous archaeologist Colin Renfrew suggests the Aryans came through Siberia by a process of diffusion from where they learned shamanism around 7000 BCE (Williams, 2009, p. 7), since, soma-Mahima ( applaud to some) in whole IX mandala of RV, is reliable to associate between chronology and geography. Among many connotations, the most influencing is-'soma as plant and an anti-fatigue hallucinogenic tonic' where Vedic sages, from their earthy experience, speculated 'always victor 
personality of Indra' and associated it with drinking soma and fighting against Vritra (William, 2009, p. 3; RV, 3. 32). War between Indra and Vritra is a multi-interpretive issue i.e. whether it was cosmic or terrestrial, physical or psychological, nevertheless, idea of 'release of cow and water' (in RV, I. 32-33: IV.18: VIII.16) is best interpreted as it was the reflection of thinking content of nomadic cattle herding Vedic people in Northern Eurasia. In the process of migration, the nomadic Aryan arrived at Sindhu Valley around 4000 BC (Kak, 1992, p. 195).

In the Rig-Veda the fight of Indra with Vrita is often represented as "a struggle for waters" or as "the striving for cows" (go-ishti), or "the striving for day" and Indra is said to have released the cows or waters, and brought on the dawn or the sun by killing Vritra (RV, I.51; II.19). To nomadic cow-keepers, their life was so deeply tied with cow and milk, since, they metaphorised even the dark cloud as cow and rain as milk, similarly, the rays of the morning as cows stepping forth from the dark stable of the night (Tilak, 1903, p. 185). Describing the dawn (Usha) with high value (RV, I. 92. 6) suggest, the Vedic bards created the hymn in polar region, where dawn comes after six months interval so it became worthy, an important and favorite Vedic deity and is celebrated in about twenty hymns of the Rig-Veda and mentioned more than three hundred times, sometimes in the singular and sometimes in the plural form (Tilak, 1903, p. 74). Another hypothesis to support the Vedic hymns were created in Arctic region is the source of Mahabharata epic- (a) according to Vanaparva of Mahavarata, Arjuna reached to North Pole, in the search of Indra on the belief of Veda to get trick of victory with never defeated Indra (Tilak, 1903, p. 64); (b) Bhishma waited Uttarayana to release soul so that he could reach to Deva Loka (RV. 10.2, 10.14, 10.16), his assumption was constructed with tradition of two-fold division of the year, one of continuous light and the other of continuous darkness which is found in arctic region.

\section{Conclusion}

The Apurusheya hypothesis assumes the Vedic knowledge as a mystic blasphemy- a cosmic knowledge for sacred preservation rather than pragmatism. Indo-Aryans delight themselves recognizing Vedas as a treasury. Contrary to this assumption, this paper through a critical evaluation of both the content and method of some 'sacred' verses came to opines a product of human endeavor. It has tried to demystify the mystified knowledge wrapped in the texts and gloriously casts light on- how the ancient scholars used to create knowledge from their skeptic and reflective ways from the sources in and around them prudent utilization of limited resources. A study of historical texts is always a tentative and open to further interrogation. This study, though, on the basis of few selected verses/hymns from Rig Veda, supports that the Vedic scholars had not used intuition as a method to create these hymns but does not support to say the hymns were the product of revealed knowledge extracted by enlightened seers with their altered state of consciousness. The study also suggests that the knowledge was produced with a normal state of consciousness by the intelligent bards and their knowledge making approach was mostly theological and slightly metaphysical. It is paradigm difficult to draw out the scientific implication the Vedic knowledge for our worldly benefits. However, it has made a trail for more comprehensive and rigorous study. Last but not least, this study on the basis of Vedic content has contributed to further clarify the concepts of speculation and intuition. 


\section{References}

Aurobindo, S. (1998). The secret of Veda. Pondicherry: Sri Aurobindo Ashram Publication.

Betsch, T. (2008). The nature of intuition and its neglect in research on judgment and decision making. In H. Plessner, C. Beltsh and T. Bletchs (Eds.). Intuition: in judgment and decision making, pp. 3-22. Psychology Press Ltd.

Bloomfield, M. (1908). The religion of the Veda. New York And London: G. P. Putnam's Sons.

Broad, C. D. (1947). Some methods of speculative philosophy. Aristotelian Society Supplement 21, $1-32$.

Burch, G. B. (1962). The place of revelation in philosophical thought. The Review of Metaphysics, 15 (3), 396-408.

Chakravartty, A. (2007). Six degrees of speculation: metaphysics in empirical contexts. In Monton, B. (Ed.). Images of empiricism. Oxford University Press.

Cowell, E. B. \& Gough, A. E. (Trans. \& Edi.). (1882). The sarva-darsana-samgraha by Madhava Acharya. Project Gutenberg.

Creswell, J. W. (2012). Educational research: planning, conducting, and evaluating quantitative and qualitative research. Boston: Pearson Education, Inc.

Culp, C. M. (2005). "What does it take to strike a spark?" Nietzsche's Apollonian/Dionysian balance in Buffy. Watcher Junior, 1.

Rickman. H. P. (1976) (ed). Diltey: selected writings. Cambridge: Cambridge University Press.

Elenjikal, A. C. (1949). The concept of god in the two earliest Upanishads. R. from http:// christianpaithrikam.com/media/system/downloads/fle_Upanishath.pdf

Ganeri, J. (1996). The Hindu syllogism: nineteenth-century perceptions of Indian logical thought. Philosophy East and West, 46(1), 1-16.

Gupta, B. (1981). Skepticism: ancient 'East' and modern 'West'. Indian Philosophical Quarterly, 9 (1), 29-44.

Hayes, R. P. \& Gillon, B. S. (1991). Introduction to Dharmakirti's theory of inference as presented in Pramanavarttika Svopajnavritti, 1-10. Journal of Indian Philosophy, 19, 1 -73.

Henriksson, Carina \& Friesen, Norm (2012). Introduction: hermeneutic phenomenology. In N. Friesen et al. (eds.). Hermeneutic phenomenology in education,1-14. Sense Publishers.

Hermanussen, M. (2003). Stature of early Europeans. Hormones 2003, 2(3), 175-178.

Kak, S. C. (1992). The Indus tradition and the Indo-Aryans. Mankind Quarterly, 32 (3), 195-207

Kirschner, P. A. (2009). Epistemology or pedagogy, that is the question. In S. Tobias \& T. M. Duffy (Eds.). Constructivist theory applied to instruction: success or failure, pp. 144-157? Routledge.

Kuzminski, A. (2008). Pyrrhonism: how the ancient Greeks reinvented Buddhism. Lexington Books.

Lieberman, M. D. (2000). Intuition: a social cognitive neuroscience approach. Psychological Bulletin, 126 (1), 109-137.

Luccio, R. (2011). The meaning of Gestalt psychology. Journal of Philosophical Studies, 17, 1-20.

Macdonell, A. A. (2012). A history of Sanskrit literature. Project Gutenberg.

Miller, J. S. (2007). Mystical experiences, neuroscience, and the nature of reality (Ph D dissertation). Florida State University, Florida.

Morris, V. C. and Pai, Y. (1976). Philosophy and the Americal school. Boston: Houghton Mifflin Company. 
Muller, F. M. (1901). Lectures on the origin and growth of religion as illustrated by the religions of India. The Hibbert Lectures in April, May, and June, 1878. Project Guttenberg.

Olliges, S. M. (2010). Shamanic and dream states of consciousness: neurochemistry and neurophysiology. Evolutionary Psychology, 8 (2): 170-172.

Pfleiderer, O. (1893). The notion and problem of the philosophy of religion. The Philosophical Review, 2 (1), 1-23.

Radhakrishnan, S. (1989). History of Indian philosophy Vol. I \&II. New Delhi: Oxford University Press Ranade, R. D. (1926). Constructive survey of Upanishadic philosophy. Poona: Oriental Book Agency.

Russell, B. (1945, 2004). A history of western philosophy. New Delhi: Oxford University Press.

Sherin, B. (2006) Common sense clarified: the role of intuitive knowledge in physics problem solving. Journal of Research in Science Teaching, 43 (6), 535-555.

Siebers, J. (2002). The method of speculative philosophy. In an essay on the foundations of Whitehead's metaphysics. Kassel University Press.

Tilak, B. G. (1903). The arctic home in the Vedas. Poona: Messrs Publishers

Williams, R. J. (2009). Soma in Indian religion: etheogens as religious sacrament. R. from www. rwilliams.us/archives/Etheogens.pdf

Winkelman, M. (2002). Shamanism as neurotheology and evolutionary psychology. American Behavioral Scientist, 45 (12), 1873-1885. 